\section{Occupational exposure to hydrogen cyanide during large-scale cassava processing, in Alagoas State, Brazil}

\author{
Exposição ocupacional ao cianeto de hidrogênio \\ durante a produção industrial da farinha de \\ mandioca no Estado de Alagoas, Brasil
}

\section{Exposición ocupacional al cianuro de hidrógeno durante la producción industrial de la harina de mandioca en el estado de Alagoas, Brasil}

\begin{abstract}
The cassava roots used for flour production contain high amounts of cyanogenic glycosides and are, therefore, potential hydrogen cyanide (HCN) releasers. This fact is the cause of an increasing health concern in the sector of cassava processing. Brazilian workers engaged in the flour production may be chronically exposed to HCN in levels above the safety limits. This hypothesis is based on the drastic reduction in cyanide content of cassava roots during a traditional Brazilian method of processing and in the physical properties of the compound, which makes it very susceptible to volatilization and air contamination. As an attempt to explore this issue, HCN exposure in Brazilian "flour houses" was evaluated in this study through environmental and biological monitoring. Four flour houses placed in Alagoas State, Brazil, were investigated. The results indicated that the cassava processors are chronically exposed to HCN at average levels between 0.464 and $3.328 \mathrm{mg} / \mathrm{m}^{3}$ (TWA), in the work environment. This range is below the TLV-C of $5 \mathrm{mg} / \mathrm{m}^{3}$ but not below the Action Level of $2.5 \mathrm{mg} / \mathrm{m}^{3}$. These data may be interpreted as a possible risk to susceptible individuals. Additionally, the biological monitoring indicated a high cyanide exposure in the population study, considering urinary thiocyanate (SCN-) levels.
\end{abstract}

Hydrogen Cyanide; Manihot; Flour Industry; Occupational Exposure
Cyro Hauaji Zacarias 1

Claudia Esteban 2

Gilson Lucio Rodrigues ${ }^{3}$

Elizabeth de Souza Nascimento 1

doi: 10.1590/0102-311X00073416

\author{
Correspondence \\ C. H. Zacarias \\ Faculdade de Ciências Farmacêuticas, Universidade de São \\ Paulo. \\ Av. Prof. Lineu Prestes 580, São Paulo, SP 05508-900, Brasil. \\ cyrohz@yahoo.com.br \\ 1 Faculdade de Ciências Farmacêuticas, Universidade de São \\ Paulo, São Paulo, Brasil. \\ 2 Faculdade de Ciências Médicas da Santa Casa de São Paulo \\ São Paulo, Brasil. \\ 3 Fundação Jorge Duprat Figueiredo de Segurança e Medicina \\ do Trabalho, Recife, Brasil.
}




\section{Introduction}

The main product of the cassava (Manihot esculenta, Crantz) processing in Brazil is the flour, a meal consumed by many social classes and representing a staple food for the low-income population, especially in regions where this activity stands out, such as in the Brazilian Northeast.

The varieties of cassava used for flour production are popularly classified as "bitter" due to the presence of high levels of cyanogenic glycosides. These intracellular compounds may be converted to hydrogen cyanide (HCN) after cell disruption, generating a potential toxicological hazard 1,2. The hazard of HCN is associated with its blockage of cellular respiratory chain, caused by the interaction between cyanide ion (CN-) and cytochrome $\mathrm{c}$ oxidase, in mitochondrial level 3,4. This property may result in acute and chronic risk to human health, depending on the exposure pattern, and the main targets of this toxicity are the central and peripheral nervous system, probably due to their high demand for aerobic energy 1 . Another described mechanism of action is the interference of its metabolite thiocyanate (SCN-) with the thyroid hormone synthesis 5. Chronically, this mechanism may result in impaired thyroid function and goiter 6 .

Considering this toxicological characteristic of the cassava roots, a process capable of detoxifying them is required to avoid consumer exposure and poisoning by food consumption. The cassava processing must guarantee a significant decrease in cyanogenic glycosides levels, the elimination of most of the HCN generated and, finally, the production of a food safe for consumption.

On the other hand, a growing concern has been the fate of HCN generated during cassava flour production and the possible biological targets beyond consumer. Brazilian flour is obtained through a basic process in which the roots are subjected to a sequence of stages: stripping, grating, pressing (wastewater release), drying (vapor emission), and sieving. Key stages for the elimination of HCN are supposed to be grating, pressing, and drying 7 . The grating and pressing generate a wastewater, popularly known as manipueira, with high content of $\mathrm{HCN}$, and the drying is the step responsible for the volatilization of the remaining $\mathrm{HCN}$ into the air 8 .

The volatilization of $\mathrm{HCN}$ to the internal atmosphere of the cassava processing facilities would represent an occupational health risk to cassava processing workers. This hypothesis had already been raised by some authors $6,9,10,11,12$.

HCN is regulated under the major international agencies responsible for occupational health, which establish maximum exposure limits for this compound in the work environment. The American agencies American Conference of Governmental Industrial Hygienists (ACGIH) and National Institute of Occupational Safety and Health (NIOSH) establish a limit of 4.7ppm for HCN in the air. This value represents a limit that cannot be exceeded at any time (ceiling value) due to the risk of acute poisoning 13 .

In addition to the measurement of HCN in the air, the controlling of exposure to cyanide in the workplace can be made through biological monitoring, which consists in the quantification of SCNin urine or blood samples. SCN- is a product of cyanide biotransformation and presents a half-life suitable for biomonitoring studies 14 .

In Brazil, the chronic exposure of cassava processors to HCN would represent an important public health problem, considering the extent to which this activity occurs in the country. In this context, adequate exposure estimation and risk characterization are essential measures. This study aimed to assess the exposure of cassava processors, from Brazilian "flour houses", to HCN and to obtain an estimate of the possible toxicological risk associated with it.

\section{Methods}

In this study, the environmental and biological monitoring were used as tools for the exposure assessment, and a clinical-laboratory evaluation was used to identify the adverse effects in cassava processing workers. The environmental monitoring consisted of HCN quantification in air samples; the biological monitoring consisted of urine sampling for SCN- quantification, and the clinical-laboratory evaluation consisted of a blood sampling for biochemical parameters assessment and a physical exam. 
For logistic reasons, the investigation was divided into three stages. The first was the selection of flour houses and the preliminary qualitative assessment of the workplaces; the second stage consisted in the environmental and biological monitoring; and finally, the physical examination was performed.

\section{Selection of flour houses}

The study was conducted in cities of Alagoas State, Brazil, where there is a high production of cassava flour, associated with a critical poverty condition and a population characterized by a low level of schooling. These characteristics were considered as critical determinants to find the worst-case scenarios in terms of occupational health.

The criteria considered for inclusion of flour houses in the study were: localization, number of workers, hygiene conditions, structure, and productivity. For logistic reasons, a priority was given to houses situated close to each other and near the central region where the team of researchers was accommodated. Flour houses with less than ten processors were excluded due to the low contribution in terms of epidemiological data. We included houses with low hygiene condition and unsuitable structure (worst scenarios) and one with better conditions (best scenario). The objective was to compare different exposure scenarios and to identify the main factors contributing for higher levels of $\mathrm{HCN}$ in the air.

\section{Qualitative preliminary assessment}

We conducted a general qualitative assessment of the health risks to which the processors were possibly exposed. Parameters such as inner area $\left(\mathrm{m}^{3}\right)$ ), level of production (tons/day), and number of ovens were raised. The temperature was registered by the personal sampling pumps used in the environmental evaluation, and the noise intensity was registered by a decibelimeter (model: DEC-415; Instrutherm Instrumentos de Medição Ltda., São Paulo, Brazil).

\section{Subjects}

Thirty-six male workers distributed in the selected flour houses were included in the study. Due to the scarcity of people available for the study, we decided to include all male subjects over 18 years who were working in the facilities at the day of visitation. All subjects were informed about the study and offered to participate voluntarily. The consensus of each worker was registered through signature of the Term of Consent. Each worker was submitted to a questionnaire for identification of possible interferential factors, to urine sampling before and after the third workday of the week for SCNmeasurement, blood sampling for biochemistry measurements before the work shift, and to a general medical examination. This research was approved by the Ethics Research Committee of the Faculty of Pharmaceutical Sciences, University of São Paulo.

\section{Air sampling}

The air sampling was conducted according to the method recommended by NIOSH (6010) 15 for HCN quantification. We used personal sampling pumps with flexible connecting tubing. The sampler (sorbent tube) consisted of a glass tube, $9 \mathrm{~cm}$ long, $7 \mathrm{~mm}$ outer diameter, $5 \mathrm{~mm}$ inner diameter, with plastic caps, containing two sections (front $=600 \mathrm{mg}$; back $=200 \mathrm{mg}$ ) granular soda lime $10 / 35 \mathrm{mesh}$, separated and contained silanized glass wool plugs, with a $5 \mathrm{~mm}$ diameter glass fiber filter disk placed before the plug on inlet side 15 .

We used sampling pumps, (VSS-5 model; A. P. Buck, Inc., Orlando, USA), which are suitable for a constant flow range from 800 to $5,000 \mathrm{cc} / \mathrm{min}(0.8$ to $5 \mathrm{~L} / \mathrm{min})$. The pumps were calibrated for a $2 \mathrm{~L} /$ min flow. As this method requires a maximum flow rate of $0.2 \mathrm{~L} / \mathrm{min}$, it was necessary to use a flow reducer (Mini-Buck Calibrator M1; A. P. Buck, Inc., Orlando, USA), for the adjustment through the sorbent tube. After the end of the work, the pumps were subjected to a new calibration to check the variability in relation to the initial calibration. 
The sampling was conducted in three consecutive days. Three points were selected in each facility: two at the breathing zone of workers and one static point, totalizing 36 samples in the four facilities after three days of evaluation. The workers monitored were those who, at the evaluation day, were working near the oven as an attempt to simulate a worst scenario in which the worker would be all the time situated in the point of higher vapor emission.

After sampling, sorbent tubes, previously identified, were properly capped and stored at room temperature. At the end of third surveillance day, the samples were immediately transported to the analytical laboratory contracted for this research.

\section{Urine and blood sampling}

For urine sampling, each worker received two sterile containers previously labeled with their full name. The workers were instructed to use one of the containers to collect the first urine in the morning (before exposure) and the other to collect the first urine after the end of the working day or after 5:00 pm.

After collected, the samples were stored during approximately $12 \mathrm{~h}$ in the refrigerator and then transferred under suitable conditions from Maceió (Alagoas State) to São Paulo, by aircraft, where the analyses were performed in a specialized commercial laboratory. The transport of urine samples was done according to requirements established by the International Airport Transport Associations (IATA).

\section{HCN and SCN- determination}

To detect and quantify HCN in air samples, we used spectrophotometric analyses recommended by NIOSH 15. After sampling, the sorbent material was solubilized and subjected to a colorimetric reaction involving an $\mathrm{N}$-chlorosuccinimide/succinimide oxidizing reagent and a barbituric acid-pyridine coupling reagent. The absorbance was read at 580nm. For SCN- determination in urine samples, the analyses also involved a spectrophotometric reaction. The method was based on the reaction among cyanogen bromide, pyridine, and p-phenylenediamine, which result in the formation of a colored pyridine complex. The spectrophotometrically measured color intensity is proportional to the SCNconcentration in urine sample.

Both the analyses were performed by contracted and ISO Guide 17025 (https://www.iso.org/ standard/39883.html) certified analytical laboratories, which gently provided the validation data of the methods, including the calibration curves.

\section{Clinical biochemistry assessment and physical examination}

Blood samples were collected and immediately sent to a local certified laboratory for biochemical analysis. The parameters assessed included hepatic enzymes, lipid profile, total proteins, serum albumin, and thyroid hormones. An occupational physician conducted a general medical exam composed by an occupational history, a standard questionnaire, and a complete physical exam.

\section{Toxicological risk characterization}

The characterization of the toxicological risk was done based on the concept of Exposure Index (EI) and of Action Level (AL), as recommended by the Brazilian occupational regulation NR-15 16. According to this regulation, the EI represents the ratio between the level quantified and the regulated occupational exposure limit (OEL), and the AL is equal to 50\% of the OEL, which was achieved with an EI higher than 0.5. An EI calculated above the AL is interpreted as posing a health risk that justifies an intervention in the workplace, due to a lack of protection of more susceptible subjects. 


\section{Statistical analysis}

The HCN concentrations in air samples were presented as the mean and standard deviation and in a box plot presenting the median and the 25th and 75th percentiles. It was applied the t-Student test for comparison between the average levels of HCN in each facility and the OEL established by different international regulations. The same approach was used for comparison between urinary SCN- average levels with an average obtained through a recent history of SCN- analyses provided by the contracted laboratory. The Pearson's correlation test was used to verify a possible association between urinary SCN- levels and blood chemistry parameters.

\section{Results}

\section{Selection of flour houses}

Five flour houses, situated in the region of the study, were selected based on the established criteria. Of the five facilities selected, one was excluded from the study due to the resistance of the proprietary, who declared to be afraid of the workers' reactions. The four flour houses included in the study were named Houses 1, 2, 3, and 4.

\section{Exposure scenario}

In addition to the possible $\mathrm{HCN}$ exposure, other potential health risks of cassava processors were identified through qualitative analyses - observation of the workplaces, processors' habits, and production process. We observed a low level of hygiene and health condition in most of the visited flour houses. During the drying stage, we observed a lack of precautions with the vapors emitted by the ovens.

During the washing of the peeled roots, the worker was in direct contact with the washing water, without personal protective equipment (PPE). The washing water, apart from containing soil impurities, may contain high levels of dissolved cyanide since the stripping stage also result in cyanogenic glycosides degradation.

The productivity, determined as tons of cassava roots per day, represents an important data in terms of exposure, as the cassava root is considered the primary source of HCN in the process. Of the four flour houses studied, only the House 4 presented productivity lower than the others and this fact was compatible with its dimension. On the other hand, the Houses 1,2 and 3 presented similar production levels. The number of ovens and dimension of each house were also a determinant parameter for potential exposure. We observed that, although the Houses 1, 2 and 3 presented similar levels of production, the reduced dimension $\left(\mathrm{m}^{3}\right)$ of Houses 2 and 3 , with the same number of ovens, provided a higher potential for exposure for these two environments.

In terms of exhaustion, none of the facilities presented a specific structure designed for this purpose, and the ventilation conditions in all the cases were considered unsuitable. Nevertheless, the House 1, by having a considerably greater inner area in relation to the others, naturally allows a greater dispersion of the vapors generated in the process. The impact of these differences in the exposure to $\mathrm{HCN}$ is discussed later in this manuscript. Table 1 summarizes the main aspects observed to characterize the exposure scenarios.

The high quantity of ovens in a closed and restricted space contributed for the increase of temperature inside the facilities. Besides the high temperature $\left(30-33^{\circ} \mathrm{C}\right)$, other consequences of the unsuitable structure included visible accumulation of particulates in the air and exposure to high level of noise generated by the grating machine. The noise intensity detected by the decibelimeter near the grating machine was in a range from 80 to $100 \mathrm{~dB}$.

Cassava processors in this region of Brazil do not have a defined workload. According to the interview, journeys of more than $20 \mathrm{~h} /$ day are possible, depending on the quantity of cassava collected. Overall, unsuitable hygiene conditions, excessive heat, high noise level, and poor ventilation were critical factors to be considered in the assessed places and warrant more detailed evaluation. 


\section{Table 1}

Parameters assessed for characterization of the exposure scenarios.

\begin{tabular}{lccc}
\hline Aspects observed & House $\mathbf{1}$ & House 2 & House 3 \\
\hline Productivity (tons/day) & $15-30$ & 15 & $15-20$ \\
Internal space (m3) & 2,140 & 276 & 843 \\
Number of ovens & 7 & 6 & 6 \\
Ventilation condition & No exhaust, poor & No exhaust, poor & No exhaust, poor \\
& ventilation & ventilation & No exhaust, poor \\
\end{tabular}

\section{Quantitative HCN exposure assessment - environmental monitoring}

Analyzing the 36 samples collected in the four flour houses included in the study, we observed an atmospheric concentration range from 0.235 to $7.77 \mathrm{mgHCN} / \mathrm{m}^{3}$. The average levels of the three days of sampling for each point varied between 0.464 and $3.328 \mathrm{mgHCN} / \mathrm{m}^{3}$. The meaning of this exposure level in terms of regulation and risk assessment is discussed hereafter in this study.

Table 2 brings the raw data of the environmental monitoring, with the time (4h) weighted average for each sample collected $(\mathrm{n}=36)$. This visualization is important for risk characterization, described further in this text.

Figure 1 represents, through a box plot, the distribution of the HCN concentrations measured in the air of flour houses. The graphic highlights a significant difference between Houses 2 and 3 compaed with Houses 1 and 4. Comparing the averages obtained in Houses 2 and 3, which presented the highest levels, it can be observed that, although House 3 have presented a higher level, the difference was not statistically significant $(\mathrm{p}>0.05)$. These findings and their relationship to the scenarios described previously are discussed later in this study.

The results obtained in the personal sampling suggest that working near the oven or near the grating machine do not interfere in the exposure potential, because after grouping the values of the four houses by point of sampling (e.g. oven, grating machine, and static point), the difference between means of each point is not statistically significant $(\mathrm{p}>0.05)$.

\section{Toxicological risk characterization based on the atmospheric HCN levels}

Among the 36 samples collected in the four flour houses during the three days of sampling, five (13.8\%) presented HCN concentration above $50 \%$ of the exposure limit of $5 \mathrm{mg} / \mathrm{m}^{3}$ established by $\mathrm{NIOSH} 17$, resulting in an EI above the AL of 0.5 . However, considering the arithmetic mean of the three sampling days, only in two points a concentration above the AL was obtained.

Comparing the mean of the nine samples obtained in each house with the AL of $2.5 \mathrm{mg} / \mathrm{m}^{3}$ through the t-Student test, we observed that Houses 1, 2 and 4 presented levels significantly lower ( $\mathrm{p}<0.001, \mathrm{p}<0.001$, and $\mathrm{p}<0.05$, respectively) than AL. In House 3, although the average was above $\mathrm{AL}$, this increase was not statistically significant $(\mathrm{p}>0.05)$. Due to the low number of samples per point $(n=3)$ and to the high variability in the concentrations, it was not possible to statistically compare these averages with the AL.

Comparing the levels obtained in flour houses with occupational standards of some more restricted European countries, such as France $\left(2.2 \mathrm{mg} / \mathrm{m}^{3}\right)$, Germany $\left(2.1 \mathrm{mg} / \mathrm{m}^{3}\right)$ and Switzerland $(2.0 \mathrm{mg} /$ $\mathrm{m}^{3}$ ), the interpretation of our results would be more concerning, as many values were near or above these limits 18 . Considering the exposure limit of $2 \mathrm{mg} / \mathrm{m}^{3}$, for example, the Houses 2 and 3 presented averages above the AL $(\mathrm{p}<0.05)$.

In Brazil, the regulation NR-15, of 1978, adopts an exposure limit for $\mathrm{HCN}$ of $9 \mathrm{mg} / \mathrm{m}^{3}$, a standard representing a time-weighted average 16 . The levels measured in the flour houses were below the Brazilian standard and none of the three daily averages exceeded the AL of $4.5 \mathrm{mg} / \mathrm{m}^{3}$, which brings us 


\section{Table 2}

Hydrogen cyanide (HCN) levels determined in air samples of four flour houses situated in Alagoas State, Brazil, with the respective means and standard deviations (SD).

\begin{tabular}{|c|c|c|c|c|}
\hline Flour house/Point of sampling & Day & Volume sampled (L) & $\mathrm{HCN}\left(\mathrm{mg} / \mathrm{m}^{3}\right)$ & Exposure index * \\
\hline \multicolumn{5}{|l|}{ House 1} \\
\hline \multirow[t]{3}{*}{ Oven man } & 1 & 46.17 & 0.44 & 0.09 \\
\hline & 2 & 45.60 & 0.49 & 0.10 \\
\hline & 3 & 45.60 & 0.46 & 0.09 \\
\hline \multirow[t]{3}{*}{ Grating man } & 1 & 48.00 & 0.49 & 0.098 \\
\hline & 2 & 42.18 & 0.65 & 0.13 \\
\hline & 3 & 36.66 & 0.60 & 0.12 \\
\hline \multirow[t]{3}{*}{ Static point } & 1 & 49.78 & 2.99 & 0.60 \\
\hline & 2 & 45.6 & 0.51 & 0.10 \\
\hline & 3 & 12.35 & 0.23 & 0.05 \\
\hline Mean \pm SD & & & $0.76 \pm 0.84$ & 0.15 \\
\hline \multicolumn{5}{|l|}{ House 2} \\
\hline \multirow[t]{3}{*}{ Oven man } & 1 & 16.15 & 2.23 & 0.45 \\
\hline & 2 & 30.59 & 2.23 & 0.45 \\
\hline & 3 & 45.07 & 1.58 & 0.32 \\
\hline \multirow[t]{3}{*}{ Grating man } & 1 & 24.60 & 1.15 & 0.23 \\
\hline & 2 & 15.30 & 3.83 & 0.77 \\
\hline & 3 & 46.75 & 1.39 & 0.28 \\
\hline \multirow[t]{3}{*}{ Static point } & 1 & 45.98 & 0.99 & 0.20 \\
\hline & 2 & 45.79 & 0.69 & 0.14 \\
\hline & 3 & 27.08 & 2.12 & 0.42 \\
\hline Mean \pm SD & & & $1.80 \pm 0.94$ & 0.36 \\
\hline \multicolumn{5}{|l|}{ House 3} \\
\hline \multirow[t]{3}{*}{ Oven man } & 1 & 22.99 & 2.93 & 0.59 \\
\hline & 2 & 16.91 & 3.61 & 0.72 \\
\hline & 3 & 19.44 & 1.77 & 0.35 \\
\hline \multirow[t]{3}{*}{ Grating man } & 1 & 46.20 & 1.23 & 0.24 \\
\hline & 2 & 51.20 & 0.99 & 0.20 \\
\hline & 3 & 11.16 & 7.77 & 1.55 \\
\hline \multirow[t]{3}{*}{ Static point } & 1 & 48.64 & 2.21 & 0.44 \\
\hline & 2 & 47.04 & 1.39 & 0.28 \\
\hline & 3 & 46.74 & 2.33 & 0.47 \\
\hline Mean \pm SD & & & $2.69 \pm 2.08$ & 0.54 \\
\hline \multicolumn{5}{|l|}{ House 4} \\
\hline \multirow[t]{3}{*}{ Oven man } & 1 & 47.5 & 1.61 & 0.32 \\
\hline & 2 & 51.11 & 0.40 & 0.08 \\
\hline & 3 & 14.63 & 1.70 & 0.34 \\
\hline \multirow[t]{3}{*}{ Grating man } & 1 & 49.20 & 1.40 & 0.28 \\
\hline & 2 & 53.40 & 0.38 & 0.08 \\
\hline & 3 & 48.80 & 0.51 & 0.10 \\
\hline \multirow[t]{3}{*}{ Static point } & 1 & 49.02 & 1.58 & 0.32 \\
\hline & 2 & 52.25 & 0.96 & 0.19 \\
\hline & 3 & 46.55 & 0.70 & 0.14 \\
\hline Mean \pm SD & & & $1.03 \pm 0.55$ & 0.20 \\
\hline
\end{tabular}

* Exposure index: ratio between measured concentration and the Occupational Exposure Limit of $5 \mathrm{mg} / \mathrm{m}^{3}$, established by the American agencies, National Institute of Occupational Safety and Health (NIOSH) and American Conference of Governmental Industrial Hygienists (ACGIH).

Note: values in bold represent the exposure index above 0.5 , the Action Level - a risk subject to intervention through actions of work environment monitoring, biomonitoring and health surveillance. 


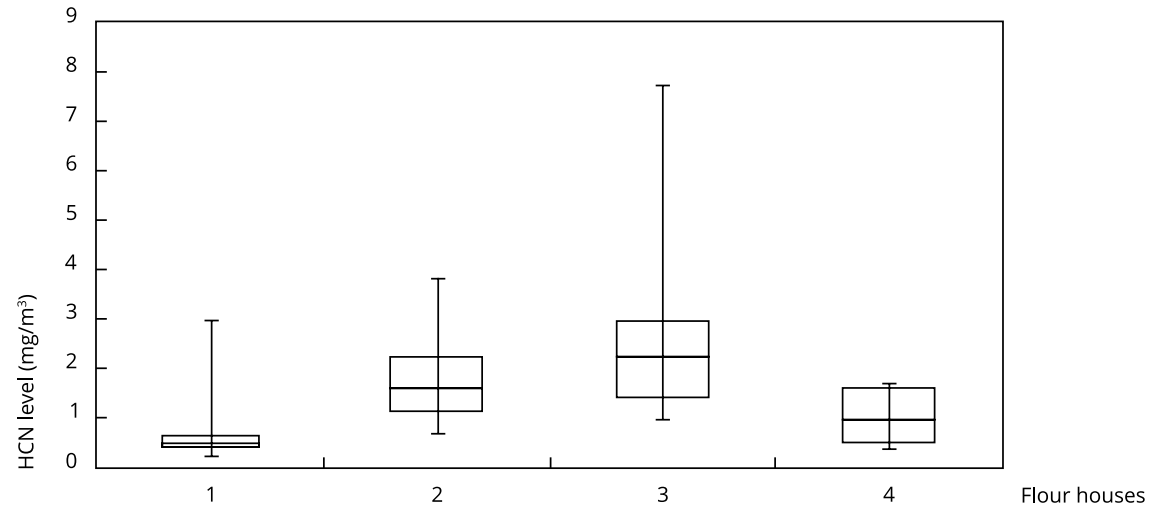

to a different interpretation and to a different rationale for decision making, in relation to using the ACGIH and NIOSH standards. This is an example of how differences between international regulations can affect the risk assessment and risk management of chemicals.

\section{Quantitative HCN exposure assessment - biological monitoring}

The Brazilian regulation NR-7 16 defines standards for biological monitoring of chemicals suspected to be present in the workplace (namely, biological exposure index - BEI). However, the BEI for HCN - urinary SCN- - was excluded from the list of NR-7 due to uncertainties surrounding this measurement. The former reference value was $2.5 \mathrm{mg} / \mathrm{g}$ creatinine $( \pm 4.0 \mathrm{mg} / \mathrm{L})$ for non-smokers.

Table 3 presents a comparison between samples collected in the beginning (first sample) and in the end (second sample) of the working day. From the 36 workers included in the study only 11 provided samples in both periods, which was considered an important limitation of the study. From these 11 workers, only four presented an increase in the urinary SCN- level from the first to the second sample. Nevertheless, as we will discuss further, the levels are elevated for both periods of collection. This unexpected result opens the hypothesis of additional important sources of exposure, beyond the workplace. One possibility would be the smoking habit, but the occurrence of higher levels in the first sample, even in non-smokers, weakens this hypothesis.

Additionally, Table 3 presents the results obtained in workers who provided samples only in the first or only in the second moment. The concentration of $13.2 \mathrm{mg} / \mathrm{g}$ creatinine detected in the sample of Subject 33, who only provided the first one, is above any other concentration detected in individuals who provided only the second sample. This observation supports the hypothesis of the existence of extra occupational sources of exposure.

We observed that $81.5 \%$ of non-smokers cassava processors presented urinary SCN- levels above the former reference value $(2.5 \mathrm{mg} / \mathrm{g}$ creatinine) for non-smokers and that $83.3 \%$ of the smokers cassava processors presented level above this index. From this result, we can deduce that smoking habit alone is not the determinant factor for the increased levels of urinary SCN- in this population. A BEI for smokers in $\mathrm{mg} / \mathrm{g}$ creatinine was not found in any reference surveyed. In a document published by NIOSH 17 , for smokers, the reference range is $2.0-20.0 \mathrm{mg} / \mathrm{L}$. After converting units, we observed a range from 7.93 to $31.41 \mathrm{mg} / \mathrm{L}$ for cassava processors with smoking habits.

The analytical laboratory contracted for the measurement of SCN- gently provided a statistical range correspondent to the results of urinary SCN- measured there in the period interval from 
Table 3

Thiocyanate (SCN-) levels ( $\mathrm{mg} / \mathrm{g}$ creatinine) in urine samples collected at the beginning (first sample) and/or at the end (second sample) of the working day in four flour houses situated in Alagoas State, Brazil.

\begin{tabular}{|c|c|c|c|c|}
\hline Subject & SCN- (first sample) & SCN- (second sample) & Ratio (second/first) & Smoking habit \\
\hline 2 & - & 10.3 & - & Smoker \\
\hline 4 & - & 2.0 & - & Nonsmoker \\
\hline 5 & - & 7.2 & - & Nonsmoker \\
\hline 6 & - & 4.7 & - & Nonsmoker \\
\hline 8 & 4.0 & 5.5 & 1.38 & Nonsmoker \\
\hline 9 & 7.4 & - & - & Nonsmoker \\
\hline 10 & - & 3.0 & - & Nonsmoker \\
\hline 13 & 2.3 & 1.8 & 0.78 & Nonsmoker \\
\hline 14 & - & 6.8 & - & Nonsmoker \\
\hline 15 & - & 11.4 & - & Nonsmoker \\
\hline 16 & - & 4.3 & - & Nonsmoker \\
\hline 17 & - & 7.5 & - & Nonsmoker \\
\hline 19 & - & 4.8 & - & Nonsmoker \\
\hline 20 & 1.3 & - & - & Not determined \\
\hline 21 & 11.0 & 2.9 & 0.26 & Nonsmoker \\
\hline 22 & 8.8 & 8.6 & 0.98 & Nonsmoker \\
\hline 23 & 17.0 & 4.8 & 0.28 & Nonsmoker \\
\hline 24 & 34.9 & 48.1 & 1.38 & Smoker \\
\hline 25 & 7.3 & 3.6 & 0.49 & Smoker \\
\hline 26 & 20.1 & 8.6 & 0.43 & Smoker \\
\hline 28 & 2.3 & - & - & Nonsmoker \\
\hline 29 & 6.1 & 2.8 & 0.46 & Smoker \\
\hline 31 & 1.1 & - & - & Nonsmoker \\
\hline 33 & 13.2 & - & - & Not determined \\
\hline 34 & 22.5 & 23.6 & 1.05 & Smoker \\
\hline 35 & 11.3 & 17.7 & 1.57 & Smoker \\
\hline 36 & - & 2.8 & - & Nonsmoker \\
\hline Mean \pm SD & $10.66 \pm 9.21$ & $8.76 \pm 10.24$ & - & - \\
\hline
\end{tabular}

SD: standard deviation.

January 1st, 2008 to April 14th, 2010. These data were used as a laboratory control. As the laboratory samples were collected from workers who were supposedly exposed to HCN, it was considered an interesting comparative basis.

The average obtained in this investigation $(\mathrm{n}=36)$ was $9.56 \mathrm{mg} / \mathrm{g}$ creatinine with a standard deviation of 9.61 and a range of results between 1.8 to $48.1 \mathrm{mg} / \mathrm{g}$ creatinine. According to the historical data provided by the laboratory, the average concentration obtained from 134 samples was $2.85 \mathrm{mg} / \mathrm{g}$ creatinine with a standard deviation of 1.34 and a range from 0.5 to $8.8 \mathrm{mg} / \mathrm{g}$ creatinine.

Despite the absence of statistically comparable data with this study, it may be recognized that the general evidence points to a high cyanide exposure in the population study, considering urinary SCN- levels.

\section{Clinical biochemistry assessment and physical examination}

Among population characteristics detected through the questionnaire, we can cite an age range between 18 and 42 years, with a mean of $27.81 \pm 7.77$, and a low schooling degree. Regarding ethnicity, $11.11 \%$ were Caucasian, $18.52 \%$ Afro descent, and $70.37 \%$ browns. Thirty seven percent referred 
to be smokers, $3.7 \%$ referred to be ex-smokers and the rest to be non-smokers. Regarding alcoholism, 85.18\% referred to be alcohol drinkers and $3.7 \%$ referred to be ex-alcohol drinkers.

The medical surveillance did not identify on the physical exam, nor in the questionnaire, alterations typically related to chronic HCN exposure, considering what have been observed in the scientific literature. The main clinical conditions detected by this investigation were probably related to other occupational stressors, such as work overload, heat, high noise intensity, and bad hygiene conditions. The main point observed through the questionnaire was the high prevalence of alcoholism (> 80\%).

The results obtained in the blood biochemistry assessment indicated a significant increase in serum activity of alkaline phosphatase, considering the Brazilian standard, with a prevalence of $93.5 \%$ hyperphosphatemia in the population studied. Serum activity of aspartate aminotransferase (AST) was increased in $30 \%$ of the population studied. These enzymatic disturbances are biomarkers of liver damage and may be associated with the alcoholism detected in most of the subjects, as discussed above. However, the occurrence of hyperphosphatemia in some subjects who declared themselves non-drinkers hinders a conclusion. The other parameters assessed were within the normal range.

A moderately negative correlation $(\mathrm{r}=-0.37)$ was observed between blood T3 levels and urinary SCN-, which would be compatible with a reduced iodine uptake in the thyroid gland normally caused by SCN-; as discussed previously, this mechanism is well described in the literature ${ }^{6}$. Despite the biological importance of this finding, the negative correlation observed is relatively weak and have no statistical significance $(\mathrm{p}>0.05)$.

\section{Discussion}

Cassava processing is an activity suspected of posing health risk to their workers due to the release of HCN in the air during some stages of the process. The scientific basis for this hypothesis was discussed, and an investigation was done with the aim of measuring the level of exposure to HCN during a working day in Brazilian flour houses. Comparing this level of exposure with reference concentrations (OELs), an estimation of the risk associated with cassava processing was obtained.

The OEL of $5 \mathrm{mg} / \mathrm{m}^{3}(4.7 \mathrm{ppm})$ adopted by both NIOSH and ACGIH represents a "ceiling" value, which, as discussed previously, means that this concentration shall not be exceeded at any time of the work shift.

In general, we observed that the atmospheric levels of HCN in the assessed flour houses are below the OEL of $5 \mathrm{mg} / \mathrm{m}^{3}$ and below the action level of $2.5 \mathrm{mg} / \mathrm{m}^{3}$. However, considering that this regulatory limit represents a "ceiling" value and that the levels obtained in this study represent time-weighted average values, it is not possible to definitely conclude that cassava processors are not exposed to levels higher than the limits at any time during the process. Increased release of HCN (possibly above OEL) at some moments of the process is expected and it would be enough to cause an adverse effect on the worker, considering the acute toxicological profile of cyanide. In addition to this assumption, we observed levels of exposure above the action level in some samples, which represents an important finding for a substance of high concern as HCN.

In other words, considering the OEL established by the American agencies NIOSH and ACGIH, we interpreted that the levels of exposure to HCN measured in the cassava processing facilities are low, but not enough to exclude a risk of acute poisoning. More research is needed to elucidate this question and, until a convincing evidence of negligible risk does not arise, management measures should be implemented.

As commented previously, the Houses 2 and 3 presented structural characteristics that provide a higher potential for exposure to inner air contaminants, including HCN. With productivity and number of ovens comparable with the House 1, the Houses 2 and 3 tend to concentrate more the contaminants generated during the process as they present dimensions considerably reduced in relation to House 1.

The factors considered determinants for the exposure assessment in each house were previously described. House 1 with an internal area of 2,140.11 $\mathrm{m}^{3}$, containing 7 ovens and processing $15-30$ tons of cassava/day presented an exposure scenario much more suitable if compared, for instance, with the 
House 3, which presented $843.6 \mathrm{~m}^{3}$, with 6 ovens and processing 15-20 tons of cassava/day. In this example, the internal area measured in each house is probably the differential factor.

The unique data found in literature regarding HCN levels in cassava processing facilities was published by Akinrele 9 . This author determined the concentration of $\mathrm{HCN}$ in air near the machines used in the different stages of cassava processing in a facility of $6,000 \mathrm{~m}^{3}$, which produced 3.5 tons of roots per day. According to this study, the sample collected near the grating machine presented a $\mathrm{HCN}$ concentration of $10 \mathrm{ppm}$, level considerably higher than the averages obtained in this study. However, the study was conducted in Nigeria and various factors including the variety of cassava, the technology applied and methodological differences make the comparison with this study of low relevance.

The results obtained in this study indicated low exposure if compared with the results obtained by El Ghawabi et al. 19, in the electroplating sector. These authors, investigating three electroplating industries, detected HCN levels in the breathing zone in a range from 4.2 to $12.4 \mathrm{ppm}$ ( 4.7 to $13.9 \mathrm{mg}$ / $\left.\mathrm{m}^{3}\right)$. The means obtained from twelve samples by each industry were $10.375 ; 6.416$, and $8.083 \mathrm{ppm}$, and this level of exposure was high enough to cause chronic adverse effects on the workers.

Chandra et al. 20, assessing the exposure to cyanide also in electroplating industry, determined $\mathrm{HCN}$ levels in the work environment in a range from 0.2 to $0.8 \mathrm{mg} / \mathrm{m}^{3}$, whereas in the breathing zone the values were from 0.1 to $0.2 \mathrm{mg} / \mathrm{m}^{3}$. Comparing the results of Chandra et al. 20 with the data obtained in this study, we concluded that cassava processing may cause an exposure to HCN comparable with an electroplating industry.

According to European Centre for Ecotoxicology and Toxicology of Chemicals (ECETOC) 18, HCN levels registered in electroplating industries varied between 0.001 and $13.9 \mathrm{mg} / \mathrm{m}^{3}$. This high variability points to the existence of many factors that may influence the HCN exposure range and justify the large range $\left(0.235\right.$ to $\left.7.77 \mathrm{mg} / \mathrm{m}^{3}\right)$ observed in this study.

Regarding experimental data information, we found one study in which an interesting comparable reference concentration for HCN in workplace air was produced. According to Fechter et al. 21, a benchmark concentration for HCN in air would be between 0.5 and 4ppm. This range was obtained in an experimental study in which rats were exposed to $\mathrm{HCN}$ via inhalation and the endpoint assessed was the capacity of the compound to increase the hearing damage caused by noise (100dB) exposure. This comparison seems to be very important considering the exposure scenario described for cassava processing in our study. The excessive noise (80-100dB) was one of the main stressors observed in the flour houses, and the data produced by Fechter et al. 21 leads us to conclude that cassava processors may have an increased risk of developing hearing damage and that HCN may be an aggravating factor for this health problem.

A biomonitoring assessment was done in an attempt to increase the power of the exposure assessment. Regarding the biomonitoring literature data, Chandra et al. 20 and Santos et al. 14 assessed cyanide exposure in galvanizing industries and found mean levels of SCN- in urine of workers below the average observed in this study. On the other hand, Okafor et al. 10 and Okafor 11, assessing cyanide exposure in cassava processors in Nigeria, found average levels of urinary SCN- surprisingly comparable with the averages detected in our study.

According to ECETOC 18, in humans, the physiological levels of SCN- in urine may vary between 2.1 and $12 \mathrm{mg} / \mathrm{L}$ in non-smokers and between 3 and $17.5 \mathrm{mg} / \mathrm{L}$ in smokers. In this study, the levels in non-smokers were between 1.29 and $21.12 \mathrm{mg} / \mathrm{L}$, while in smokers the values varied from 7.93 to $31.41 \mathrm{mg} / \mathrm{L}$. When evaluating individual data from this study we observed that some workers were exposed to levels of cyanide much higher than the average expected in terms of physiology.

Few available data associate cyanide exposure with the hepatic biochemical disturbances 6,10,18 observed in this assessment. ECETOC 18 made reference to an unpublished occupational study where it was found increased alkaline phosphatase in 10 of 15 workers supposedly exposed to cyanide in a galvanizing industry, but without an exposure measurement. Okafor et al. 10 evidenced increased serum activity of AST in 4 of 10 female cassava processors exposed to HCN in Nigeria against none alteration in a comparison control group of cassava consumers. An increase, with a marginal statistical significance, in AST activity, was also observed in cassava processors in relation to a control group by Dhas et al. 6 . These evidences are very weak to establish a causal relationship with occupational HCN exposure and the possibility of non-occupational exposures shall be considered. 
Our study provided evidence that Brazilian workers of flour houses may be chronically exposed to low levels of HCN released into the air during cassava processing. The exposure levels measured justify the need of risk management measures, considering the occupational standards established by NIOSH and ACGIH and the occurrence of some air samples overcoming the named "action level". The biological monitoring indicated high cyanide exposure in some subjects, disregarding the smoking habits. However, the absence of a standard reference value and of a negative control group compromised the interpretation of these data.

The blood chemistry assessment indicated high prevalence of liver damage through the increased activity of AST and alkaline phosphatase, but without detection of a direct correlation with occupational exposure to HCN. A high consumption of alcoholic beverages, identified in this population by interview, may be the main etiologic factor for these enzymatic alterations. Dhas et al. 6 found decreased blood levels of T4 in cassava workers compared with a control group, suggesting an insufficient iodine uptake by thyroid gland. This result was not obtained in this study.

The medical examination did not detect any characteristic symptom of occupational cyanide exposure. The clinical data showed diseases related to bad social economical and hygiene condition, such as decays, alcoholism and mycosis, reflecting the poverty and bad working condition of these populations. Typical complaints such as headache, dizziness, vomiting, eye irritation, breathing difficulties and chest pain, detected by Dhas et al. 6 , in cassava processing workers, were not evidenced in our study.

\section{Conclusion}

This first exploratory study presents important methodological limitations, such as the lack of an adequate control group, the small sample size and many other details related to our weak logistic conditions, besides the study design utilized, which is not sufficient for causality establishment. Nevertheless, the evidence produced here still requires future population studies with a better capacity for causality definition. Case-controls and cohort designs are more powerful for these purposes and are recommended for future assessments.

\section{Contributors}

C. H. Zacarias contributed to study design, collection, analysis and interpretation of the data, and writing of the article. C. Esteban contributed to the data analysis and writing of the article. G. L. Rodrigues contributed to collection and analysis of the data. E. S. Nascimento contributed to study design, analysis and interpretation of the data, and writing of the article.

\section{Acknowledgments}

The authors thank Mr. Nelson Vieira, from SEBRAE/Alagoas, for the partnership and collaboration in the access to the cassava processing facilities. This study was supported by the Brazilian agencies $\mathrm{CNPq}$, through the fellowship, FAPESP, through the project financial support, and FUNDACENTRO, through the support for sampling and data analysis. 


\section{References}

1. Nzwalo H, Cliff J. Konzo: from poverty, cassava, and cyanogen intake to toxico-nutritional neurological disease. PLoS Negl Trop Dis 2011; 5:e1051.

2. Murugan K, Sekar K, Al- Sohaibani1 S. Detoxification of cyanides in cassava flour by linamarase of Bacillus subtilis KM05 isolated from cassava peel. Afr J Biotechnol 2012; 11:723237.

3. Hodgson EA. Textbook of modern toxicology. 3rd Ed. Stamford: Appleton \& Lange; 2004.

4. Fortin J, Desmettre T, Manzon C, Judic-Peureux V, Giocanti JP, Hachelaf M, et al. Cyanide poisoning and cardiac disorders: 161 cases. J Emerg Med 2010; 38:467-76.

5. Brauer VF, Below H, Kramer A, Führer D, Paschke R. The role of thiocyanate in the etiology of goiter in an industrial metropolitan area. Eur J Endocrinol 2006; 154:229-35.

6. Dhas PK, Chitra P, Jayakumar S, Mary AR. Study of the effects of hydrogen cyanide exposure in Cassava workers. Indian J Occup Environ Med 2011; 15:133-6.

7. Chisté RC, Cohen KO, Mathias EA, Oliveira SS. Quantificação de cianeto total nas etapas de processamento das farinhas de mandioca dos grupos seca e d'água. Acta Amaz 2010; 40:221-6.

8. Cagnon JR, Cereda MP, Pantarotto S. Vol. 2 cultura de tuberosas amiláceas latino-americanas [CD-ROM]. São Paulo: Fundação Cargill; 2002.

9. Akinrele IA. Hydrocyanic acid hazard during large scale cassava processing. Trop Sci 1986; 26:59-65.

10. Okafor PN, Okorowkwo CO, Maduagwu EN. Occupational and dietary exposures of humans to cyanide poisoning from large scale cassava processing and ingestion of cassava foods. Food Chem Toxicol 2002; 40:1001-5.

11. Okafor PN. Assessment of cyanide overload in cassava consuming populations of Nigeria and the cyanide content of some cassava based foods. Afr J Biotechnol 2004; 3:358-61.

12. World Health Organization. Extracts from the occupational hazards section of the anthology on women health and environment. Geneva: World Health Organization; 1994.
13. Occupational and Safety Health Administration. Occupational safety and health guideline for hydrogen cyanide 2011. http://www.osha. gov/SLTC/healthguidelines/hydrogencya nide/recognition.html.

14. Santos UP, Settini MM, Filho VW, Bussacos MA. Uso de tiocianato urinário como biomarcador de exposição a cianetos. Rev Bras Saúde Ocup 1990; 18:71-3.

15. National Institute of Occupational Safety and Health. Manual of analytical methods (NMAM). 4th Ed. Washington DC: National Institute of Occupational Safety and Health; 1994. (Publication, 94-113).

16. Ministério do Trabalho e Emprego. Portaria no 3.214, de 08 de junho de 1978. Diário Oficial da União 1978; 6 jul.

17. National Institute of Occupational Safety and Health. Health Hazard Evaluation report: Summitville Consolidated Mining Company, Inc., 1988. (HETA 88-022-1926). http://www.cdc.gov/niosh/hhe/reports/ pdfs/1988-0022-1926.pdf.

18. European Centre for Ecotoxicology and Toxicology of Chemicals. ECETOC JACC REPORT n. 53: hydrogen cyanide, sodium and potassium cyanides and acetone cyanohydrin (CAS n. 74-90-8, 143-33-9, 151-50-8 and 7586-5), 2007. http://members.ecetoc.org/Docu ments/Document/JACC\%20053\%20Vol\%20I. pdf.

19. El Ghawabi SH, Gaafar MA, El-Saharti AA, Ahmen SH, Malash KK, Fares R. Chronic cyanide exposure: a clinical, radio isotope and laboratory study. Br J Ind Med 1975; 32:215-9.

20. Chandra H, Gupta BN, Bhargava SK, Clerk $\mathrm{SH}$, Mahendra PN. Chronic cyanide exposure: a biochemical and industrial hygiene study. J Anal Toxicol 1980; 4:161-5.

21. Fechter DL, Chen G, Johnson D. Potentiation of noise-induced hearing loss by low concentrations of hydrogen cyanide in rats. Toxicol Sci 2002; 66:131-8. 


\section{Resumo}

As raizes da mandioca utilizadas na produção de farinha contêm altos teores de glicosídeos cianogênicos; portanto, representam fontes potenciais de liberação de cianeto de hidrogênio. Esse fato causa preocupação crescente quanto à saúde dos trabalhadores na indústria de processamento da mandioca. Os trabalhadores brasileiros na produção da farinha de mandioca podem estar cronicamente expostos ao cianeto de hidrogênio em níveis acima dos limites seguros. Essa hipótese é baseada na redução drástica do nível de cianeto nas raízes da mandioca durante o método tradicional de processamento no Brasil, e nas propriedades físicas do composto, fazendo com que seja altamente suscetível à volatilização e à contaminação atmosférica. Para explorar essa questão, o estudo avaliou a exposição ao cianeto de hidrogênio em casas de farinha brasileiras através da monitorização ambiental e biológica. Foram estudadas quatro casas de farinha localizadas no Estado de Alagoas. Os resultados mostraram que os trabalhadores no processamento da mandioca estão expostos cronicamente ao cianeto de hidrogênio em níveis médios entre 0,464 e 3,328mg/m $\mathrm{m}^{3}$ (TWA). Essa faixa é abaixo do TLV-C de $5 \mathrm{mg} / \mathrm{m}^{3}$, mas não abaixo do Nível de Ação de 2,5mg/m 3 . Os dados podem ser interpretados como de risco potencial para os indivíduos suscetíveis. Além disso, a monitorização biológica indicou exposição elevada ao cianeto na população do estudo, considerando os níveis urinários de tiocianato.

Cianeto de Hidrogênio; Manihot; Indústria de Farinhas; Exposição Ocupacional

\section{Resumen}

ELas raíces de la mandioca, utilizadas en la producción de harina contiene altas proporciones de glucósidos cianogénicos; por tanto, representan fuentes potenciales de liberación de cianuro de hidrógeno. Este hecho causa una preocupación creciente, en cuanto a la salud de los trabajadores en la industria de procesamiento de la mandioca. Los trabajadores brasileños en la producción de harina de mandioca pueden estar crónicamente expuestos al cianuro de hidrógeno a niveles superiores de los límites seguros. Esta hipótesis está basada en la reducción drástica del nivel de cianuro en las raíces de la mandioca durante el método tradicional de procesamiento en Brasil, y en las propiedades físicas del compuesto, provocando que sea altamente susceptible a la volatilización y a la contaminación atmosférica. Para explorar esta cuestión, el estudio evalúo la exposición al cianuro de hidrógeno en fábricas de harina brasileñas, a través de la monitorización ambiental y biológica. Se estudiaron cuatro fábricas de harina localizadas en el estado de Alagoas. Los resultados mostraron que los trabajadores en el procesamiento de la mandioca están expuestos crónicamente al cianuro de hidrógeno en niveles medios entre 0,464 y 3,328mg/ $m^{3}$ (TWA). Esta franja está por debajo del TLV-C de $5 \mathrm{mg} / \mathrm{m}^{3}$, pero no por debajo del nivel de acción de 2,5mg/m3. Los datos pueden ser interpretados como de riesgo potencial para los individuos susceptibles. Además, la monitorización biológica indicó exposición elevada al cianuro en la población del estudio, considerando los niveles urinarios de tíocianato.

Cianuro de Hidrógeno; Manihot; Industria Harinera; Exposición Profesional
Submitted on $01 /$ May/2016

Final version resubmitted on 20/Jul/2016

Approved on 24/Aug/2016 